\title{
Financial Feasibility Assessment of Sweet Potato Cultivation Technology Packages Application in Tidal Swamp Land
}

\author{
Nila Prasetiaswati ${ }^{1}$, Yusmani Prayogo ${ }^{1}$, Marida S. Y. I. Bayu ${ }^{1}$, Sumartini ${ }^{1}$, Yudi Widodo ${ }^{1}$, Sri W. Indiati ${ }^{1}$, \\ Fachrur Rozy ${ }^{1} \&$ Made J. Mejaya ${ }^{1}$ \\ ${ }^{1}$ Indonesian Legumes and Tuber Crops Research Institute (ILETRI), Malang, East Java, Indonesia \\ Correspondence: Made J. Mejaya, Indonesian Legumes and Tuber Crops Research Institute (ILETRI), Jl.Raya \\ Kendalpayak, KM 08, P.O. Box 66 Malang 65101, East Java, Indonesia. Tel: 62341-801468. E-mail: \\ mmejaya@yahoo.com
}

Received: December 29, 2020

Accepted: January 28, $2021 \quad$ Online Published: February 15, 2021

doi:10.5539/jas.v13n3p113

URL: https://doi.org/10.5539/jas.v13n3p113

The research is financed by the 2019 ILETRI research and development program.

\begin{abstract}
Sweet potato is consumed as a source of carbohydrate as a substitute for essential food (rice). Due to limited area in Java island, Indonesia, the expansion of sweet potato could be cultivated in tidal swamp land. Therefore, this research was aimed to determine the financial feasibility of sweet potato technology packages in tidal swamp field. This research was carried out in tidal swamp fields: Roham Village, Wanaraya District, Barito Koala Regency, and South Kalimantan Province, Indonesia from March to July 2019. This study compared two innovative and existing technologies. The innovative technology introduced to the farmers emphasized on intensive processing in order to reduce the occurrence of the main pests of sweet potato in tidal fields. Innovative technologyy includes tillage done with plows and rakes. The results of this research showed that application of sweet potato cultivation technology packages with improved tillage, land cover with mulch, pest control using chemical fungicides and shallot extracts has proven to be financially feasible. Existing farmers (local variety) who switch to innovative technology using Sari variety, the profit earned increased by $232.47 \%$. Technically, the application of the tuber yield innovative technology for Sari variety was higher, both controlled using chemical insecticides and innovative technology of 18.25 and 24.15 tons/ha, respectively. The implementation of the introduced cultivation technology package was able to increase local sweet potato production to the superior Sari variety by $96.82 \%$ compared to the farmer technology package at the same location. $\mathrm{R} / \mathrm{C}$ and $\mathrm{B} / \mathrm{C}$ ratio $>1$ for innovative technology shows that innovation technology is feasible to be developed at the researched location.
\end{abstract}

Keywords: cultivation technology, financial feasibility, sweet potato, tidal land

\section{Introduction}

Sweet potato (Ipomoea batatas L.) in Indonesia is considered as secondary crop (palawija) after rice, which is consumed as a source of carbohydrate as a substitute for essential food (rice). Sweet potato mostly cultivated in Java island either in upland or in rainfed lowland after rice. However due to limited area in Java, the expansion of sweet potato could be cultivated in tidal swamp land. In Indonesia the tidal swamp land is quite large, reaching 33 million hectares, most of which are potential land for the development of cassava and sweet potato (Nugroho et al., 1992). The latest digitization result of tidal swamp land in Indonesia that was 34.93 million ha (BBSDLP, 2014).

In 2018, the provinces of West Java, East Java and Central Java contributed a total of $36.48 \%$ of national production, followed by the provinces of Papua, East Nusa Tenggara and North Sumatra, which contributed with $17.38 \%, 8.89 \%$, and $5.54 \%$, respectively. The national productivity of sweet potato reached $18.02 \mathrm{t} / \mathrm{ha}$, which is still much lower than the yield potential of several superior varieties which reach 25-30 t/ha of fresh tubers (BPS, 2018). This shows that the potential to increase production through the development of planted areas is still very large. Considering that the development must be adjusted for areas that have agro-climatic compatibility with sweet potatoes. 
Steady swamp land in South Kalimantan is around 208,893 ha which is divided into three groups, namely organic soil (peat), river sediment mineral soils (embankments), and mineral soils of marine sediment, by which about 37\% of this area has been used for agriculture (Arifin et al., 2006; Raihana, 2012; Arsyad, 2014; Panggabean \& Wiryawan, 2016; Salamiah \& Kumalawati, 2017). However, the land use still faces various obstacles, namely in the form of physico-chemical land. According to Sarwani et al. (1994) these obstacles were in the form of waterlogging, land physical conditions, high soil acidity, presence of toxic substances ( $\mathrm{Al}, \mathrm{Fe}$ and $\mathrm{H}_{2} \mathrm{~S}$ ), saltwater intrusion, and low soil fertility.

Sweet potato has the opportunity to be cultivated in the tidal swamp lands of South Kalimantan. Sweet potato production in this province reached 23,421 tons in 2014 with a productivity of 12.9 tons/ha (BPS, 2018). According to the report of Notohadiprawiro and Maas (2006), the productivity of cassava and sweet potato in tidal land is still low. Therefore, it is the opportunity to improve sweet potato productivity through land management physically, biologically, and chemically. Barito Koala Regency, South Kalimantan Province, is one the sweet potato production area, however it has several problems such as the presence of endemic cylas and scab diseases resulting in low tuber yield. The sweet potato cultivated by the local community is a local variety with superior taste, but it is very susceptible to tuber borer attack caused by Cylas formicarius and scab disease caused by Sphaceloma batatas (Prayogo \& Bayu, 1991).

The emergence of these pests and diseases also occur in the dry season when many tubers are exposed due to the break of soil surface. With the addition of mulch, the enlargement of width and height of mounds, as well as soaking of the land, the tubers formed will be protected from C. formicarius imago (Chalfant et al., 1990; Chalker-Scott, 2007; Dada et al., 2020).Several research results indicated that the productivity of sweet potato in tidal fields reached $10-20.22$ tons/ha with local varieties and depends on the use of fertilization inputs and land preparation (Galib, 2014; Faidah et al., 2015). Widodo et al. 2018 reported that in 2017, Simpangjaya, South Kalimantan, sweet potato variety Beta 3 yielded 14.66 tons/ha which was higher than the local variety (10.72 tons/ha). Zahoor et al. (2016) and Laxminaraya et al. (2016) suggested to produce sweet potato with productivity of $15.39 \mathrm{tons} / \mathrm{ha}$ can be conducted by applying fertilizer of $100 \mathrm{~kg}$ of Phonska +10 tons of manure +5 tons of litter as mulch $+750 \mathrm{~kg} / \mathrm{ha} \mathrm{lime} \mathrm{(dolomit).}$

Land management could be conducted using technology components consisted of superior varieties, dolomite, land covering with straw mulch, enlargement of the width and height of the mounds, increasing the dosage of organic and inorganic fertilizers, as well as controlling tuber borer using the entomopathogenic fungus Beauveria bassiana and scab disease using vegetable pesticides from shallot extract. The superior variety used was Sari which has early maturity (3.5 months), resistance to the main pests of sweet potato, namely boleng (Cylas formicarius), and high productivity (40 tons/ha). Application of dolomite (lime) increased the efficiency of Phosphorus (P) fertilization, even extracting soil P bound by Aluminium ( $\mathrm{Al}$ ) or Iron (Fe) (Subiksa et al., 1998), could inhibited the rate of soil acidification (Smith, 1997; Hartatik et al., 1999; Abiodun, 2010; Chen et al., 2017).

The use of mulch from rice straw and other crop residues can be used to replace the function of turning (lifting) the sweet potato tendrils, making it more efficient economically. Additional mound width and height are needed so that the tubers are well protected or covered with soil. One of the several ways to increase soil and plant productivity and environmental sustainability is through an integrated nutrient system that combines organic fertilizers with inorganic fertilizers. Organic fertilizers were usually given together with the manufacture of mounds. Manure as much as $10 \mathrm{t} / \mathrm{ha}$ without the addition of inorganic fertilizers was able to produce sweet potato up to 28 tons/ha, harvested at four months of maturity age in alluvial soil (Widodo et al., 2018). According to Waluyo and Mok (1994), the intensity of boleng pest attacks in the dry season increased by up to $70 \%$. Therefore, the biological control use entomopathogenic fungus B. bassiana and botanical pesticide of shallot extracts can be relied on to suppress the main pest and disease attack of sweet potato (Abiodun, 2010; Sumartini, 2014; Saputro et al., 2019). The sweet potato cultivation technology package may increase farmers' production and income, therefore, the current experiment was undertaken with the objective to determine the financial feasibility of sweet potato technology packages in tidal swamp fields.

\section{Method}

\subsection{Location and Time of Research}

This research was carried out in tidal swamp fields, Roham Village, Wanaraya District, Barito Koala Regency, South Kalimantan Province, Indonesia from March to July 2019. The location determination was carried out purposively by considering that sweet potato was a nominated food crop commodity. However, it had problems with the presence of endemic cylas and scab diseases resulting in low yielding local varieties. The research 
covered an area of 2.0 ha which consisted of 1.0 ha of farmer's existing technology and 1.0 ha of innovation technology.

\subsection{Research Approach}

This study compared two technologies, named innovative and existing technologies. The innovative technology introduced to the farmers emphasized on intensive processing in order to reduce the occurrence of the main pests of sweet potato in tidal fields. Innovative technology include: tillage done with plows and rakes. The varieties used were superior variety Sari and local variety (used as a check or comparison). Dolomite was given by mixing it with manure and for the ground cover as much as 2 tons/ha of straw mulch was laid. The mounds measure 150 $\mathrm{cm}$ wide and $60 \mathrm{~cm}$ high. They were given 3 tons/ha of organic and inorganic fertilizers, manure and $400 \mathrm{~kg} / \mathrm{ha}$ of Phonska. Tuber borer control was done using the entomopathogenic fungus Beauveria bassiana and scab disease was done using vegetable pesticides from shallot extract.

The existing technology was a recommended technology commonly used by farmers. Existing technology consisted of various components, almost the same as the innovative technology component. The striking difference in the existing technology was that the land was not covered using mulch, pest and diseases were controlled using chemical pesticides, in addition to increasing the dosage of fertilizer and dolomite. The components of both existing and innovative technologies in sweet potato production in tidal fields is presented in Table 1.

Data and observations made include costs and farm yields. Analysis to show an increase in farmer's income was carried out by input-output analysis. The data collected was primary obtained from direct observation and recording of farmers who were directly involved in sweet potato cultivation research activities which include soil cultivation, planting, fertilization, weeding, pest control and harvesting. Data related to technical aspects recorded were the yield of healthy sweet potato tubers. Data related to the financial aspects collected were: (a) used and cost of inputs, (b) used and financing of labor, (c) Revenues by farmers from sweet potato production, (c) Selling prices, (d) Use of fertilizers and pesticides (needs and purchase costs), and (e) Use of labor (number and costs of labor for various activities).

\subsection{Types of Data and Analysis Methods}

\subsubsection{Data Collection Technique}

The data used in this study came from secondary and primary data. Primary data collection was carried out by means of observation, and direct interviews using a questionnaire, while secondary data was obtained from various sources, namely various agencies related to this research, both at the provincial and district levels as well as from various literatures. Data collection includes sweet potato cultivation activities, namely land preparation, planting, weeding, pest control and harvesting. This data was needed to obtain information on financial aspects, however, the technical aspects were still being observed as supporting data.

\subsubsection{Data Analysis}

Economic feasibility analysis was used to see how much income and sweet potato production was produced by farmers using both existing and innovative technologies. Farm income was counted by analyzing the cost and income of farming (Lipsey, 1997). Mathematically it can be written as follows (Rahim \& Hastuti, 2007):

$$
\pi=\mathrm{TR}-\mathrm{TC}
$$

where, $\pi=$ Profits from sweet potato farming $(\mathrm{Rp}) ; \mathrm{TR}=$ Total revenue from sweet potato farming $(\mathrm{Rp})$; $\mathrm{TC}=$ Total cost of sweet potato farming (Rp).

Qualitative data analysis used descriptive methods to explain the characteristics of farmers. The quantitative data analyzed were farm income, Break Event Point (BEP), revenue and cost $(\mathrm{R} / \mathrm{C})$ ratio, Benefit Cost $(\mathrm{B} / \mathrm{C})$ Ratio, and Marginal Benefit Cost (MBC) Ratio. Farming revenue is a multiplication between the production obtained by the farmer and the selling price This definition can be formulated as follows:

$$
\mathrm{a}=\mathrm{R} / \mathrm{C}
$$

where, $\mathrm{R} / \mathrm{C}=$ ratio of revenue and cost; $\mathrm{R}=$ revenue $(\mathrm{Rp} / \mathrm{ha}) ; \mathrm{C}=\operatorname{Cost}(\mathrm{Rp} / \mathrm{ha})$.

With a decision:

$\mathrm{R} / \mathrm{C}>1$, farming is economically profitable;

$\mathrm{R} / \mathrm{C}=1$, farming is economically at the break-even point (BEP);

$\mathrm{R} / \mathrm{C}<1$, farming is not economically profitable (loss). 
It is believed that the profit or value of the introduced technology package is higher than the farmer's technology package. For that, the feasibility of the two types of technology packages (farmer method and introduced technology packages) need to be known. Farming feasibility was a measure to determine whether this business is feasible or not feasible. Here in the sense of whether it can produce a benefit or not. To determine the feasibility level of changes in technology innovation components, use the break-even point analysis approach (BEP production) and the price break-even point (BEP price) using the analysis of losses and gains through marginal $\mathrm{B} / \mathrm{C}$ or the ratio of profit and marginal costs $(\mathrm{MBC})$ ratio. Benefit Cost Ratio $(\mathrm{B} / \mathrm{C}$ ratio) is calculated based on the equation:

$$
\mathrm{B} / \mathrm{C} \text { ratio }=\text { Total Cost } / \text { Total Production }
$$

where,

If the $\mathrm{B} / \mathrm{C}$ ratio $>0$ means that the farming has potential financial to develop;

If the $\mathrm{B} / \mathrm{C}$ ratio $=0$ it means that the farm is at point break-even (BEP);

If the $\mathrm{B} / \mathrm{C}$ ratio $<0$, it means that the farming has no potential financially to develop.

To find a point, in units or rupiah, that shows costs equal to income, a break event point (BEP) analysis is used (Hidayah, 2016). According to Malian (2004), the Marginal Benefit Cost (MBC) Ratio is calculated based on the following equation:

$$
\text { MBC Ratio }=(\text { Gross receipts of I }- \text { Gross receipts of } \mathrm{P}) /(\text { Total cost of } \mathrm{I}-\text { Total cost of } \mathrm{P})
$$

where, $\mathrm{I}=$ Innovation Technology; $\mathrm{P}=$ Existing Technology.

If the MBC Ratio value is $>1$, then the pesticide-free technology package is considered economically feasible. Break Event Point (BEP) is calculated by differentiating production BEP and price BEP with the following equations:

$$
\begin{gathered}
\text { BEP Production }=(\text { Cost of production }) /(\text { Price of production }) \\
\text { BEP Price }=(\text { Cost of production }) / \text { Productivity }
\end{gathered}
$$

\section{Results and Discussion}

\subsection{Sweet Potato Productivity}

The implementation of the introduced cultivation technology package was able to increase local sweet potato production to the superior Sari variety by $96.82 \%$ compared to the farmer technology package at the same location. This occured especially with the superior sweet potato varieties that have the opportunity to be widely used. From this research, the application of existing technology components, both on local varieties and superior varieties of Sari, were able to produce tuber yield of 12.27 and 18.25 tons/ha, respectively. These results were still far from the potential of research results (Sari variety) which can reach 30.0-35.0 tons/ha (BALITKABI, 2016).

By using innovation technology, the tuber yield for Sari variety was higher, both in controlled using chemical insecticides and innovative technology, $18.25 \mathrm{t} /$ ha and $24.15 \mathrm{t} / \mathrm{ha}$, respectively (Figure 1). Giving straw mulch to sweet potato plantations increased the yield of sweet potatoes, in addition to suppressing weed growth, maintaining moisture and soil fertility. 


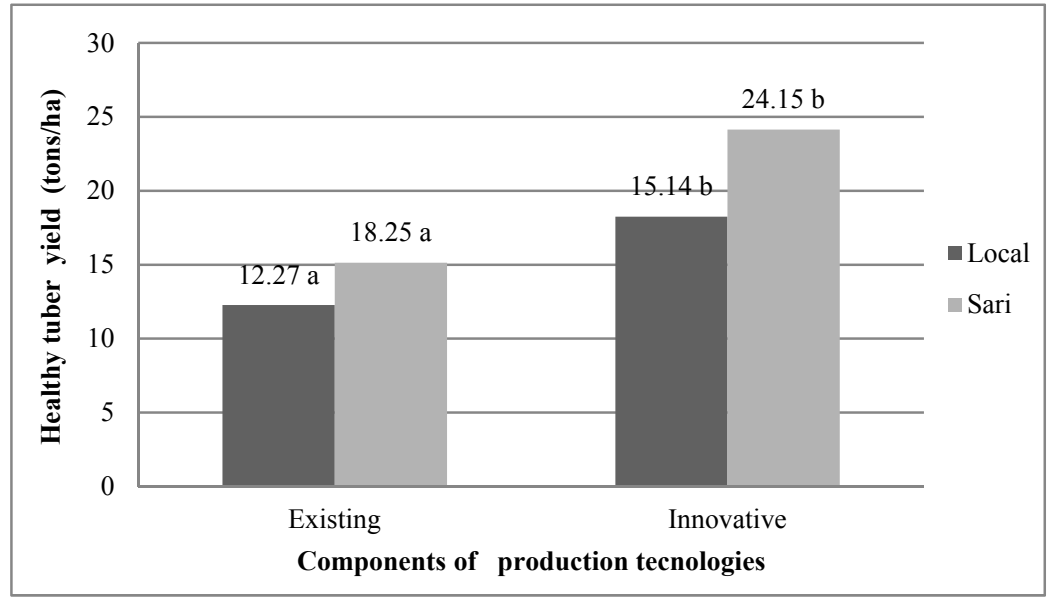

Figure 1. Average yield of local variety and superior Sari variety using chemical insecticides (existing) and land management (innovative) technologies

\subsection{Cost Structure and Feasibility of Cultivation Technology}

\subsubsection{Input Requirements}

The results of economic farming analysis at the research level showed that the use of innovative technology required higher input costs than existing technology (Table 1). The high cost was due to the high production facilities in the form of increasing the amount of dolomite and manure of 1 ton/ha each, $200 \mathrm{~kg} / \mathrm{ha}$ of Phonska fertilizer and the availability of straw mulch, the cost was Rp. 7,300,000 (equal to 521.43USD)/ha, while in the existing technology reached Rp 2,100,000 (149.99 USD)/ha. The use of fungus biopesticide (B. bassiana) and vegetable pesticides reached $\mathrm{Rp} 2,450,000$ (175.00 USD)/ha or $10.86 \%$ of the total input costs, whereas in existing technology, insecticides and fungicides were required at a cost of Rp 1,359,000 (97.07 USD)/ha or $8.36 \%$ of total input costs. The total input costs for existing and innovative technology were Rp 22,550,000 (1610.71 USD) and Rp 16,259,000 (1161.36 USD)/ha, respectively. If farmers want to switch to using innovative technology, the costs required to provide production facilities were Rp 6,291,000/ha (449.36 USD) or increased by $38.69 \%$.

Tabel 1. Material input costs for the innovative package and existing sweet potato cultivation technologies in the tidal area of Barito Koala Regency, South Kalimantan, Indonesia, 2019

\begin{tabular}{|c|c|c|c|c|c|c|}
\hline \multirow{3}{*}{ Descriptions } & \multicolumn{6}{|c|}{ Production Technologies } \\
\hline & \multicolumn{3}{|c|}{ Innovative } & \multicolumn{3}{|c|}{ Existing } \\
\hline & $(\mathbf{R p}) *$ & (USD)* & $(\%)$ & (Rp) & (USD) & $(\%)$ \\
\hline Stem cuts for planting & $12,800,000$ & 914.29 & 56.76 & $12,800,000$ & 914.29 & 78.73 \\
\hline Phonska & $1,000,000$ & 71.43 & 4.43 & 500,000 & 35.71 & 3.08 \\
\hline Manure & $1,200,000$ & 85.71 & 5.32 & 800,000 & 57.14 & 4.92 \\
\hline Dolomite & $1,600,000$ & 114.29 & 7.10 & 800,000 & 57.14 & 4.92 \\
\hline Mulch straw & $3,500,000$ & 250.00 & 15.52 & - & - & - \\
\hline B. bassiana (fungus biopesticide) & $1,250,000$ & 89.29 & 5.54 & - & - & - \\
\hline Shallot extract (herbal pesticide) & $1,200,000$ & 85.71 & 5.32 & - & - & - \\
\hline Insecticide & - & - & - & 839,000 & 59.93 & 5.16 \\
\hline Fungicide & - & - & - & 520,000 & 37.14 & 3.20 \\
\hline Total input costs/ha & $22,550,000$ & 1610.71 & 100.00 & $16,259,000$ & 1161.36 & 100.00 \\
\hline
\end{tabular}

Note. * 1.0 USD (US Dollar) $=$ Rp 14,000 (Indonesian Rupiah).

\subsubsection{Labor Requirement}

Sweet potato farming used a lot of male labor because of the heavy work involved in land cultivation, planting and harvesting. Leovita et al. (2015) stated that labor was the biggest farming cost component in sweet potato 
farming. The use of labor involved elements of labor in the family and also outside the family. Therefore, the costs calculated in this study included labor costs in the family. The use of labor in the family did not burden the farmers too much in terms of financing their farms. Wages differ according to their activities. For the activities of tillage, plotting for planting pads, and mounting, the payment was made in bulk of Rp 1,500,000 (107.14 USD)/ha, Rp 7,000,000 (500.00 USD)/ha, and Rp 4,500,000 (321.43 USD) /ha, respectively. However for planting, fertilizing, controlling pests and diseases, turning tendrils and harvesting harvest, farmers provided a wage of $\mathrm{Rp} 55,000$ (3.93 USD)/4.5 hours.

Cultivation and harvesting activities required a lot of manpower (labor). Land processing was done by workers outside the family, while for planting, fertilizing, controlling pests and diseases, turning tendrils and harvesting are carried out by workers within and outside the family. The addition of labor input for land processing activities is $41.67 \%$ higher than the existing method. This was due to the technology innovation, doing the plowing and rake activities twice each. However, the workforce for pest control and innovation technology was $11.11 \%$ lower than the existing technology. If farmers switch to innovative technology, the costs required for labor increased by $24.36 \%$. The labor input costs for the innovation package and the existing sweet potato cultivation is presented in Table 2 .

Table 2. Labor input costs of sweet potato cultivation technologies in the tidal swamp area of Barito Koala Regency, South Kalimantan, Indonesia, 2019

\begin{tabular}{|c|c|c|c|c|c|c|}
\hline \multirow{3}{*}{ Descriptions } & \multicolumn{6}{|c|}{ Production Technologies } \\
\hline & \multicolumn{3}{|c|}{ Innovative } & \multicolumn{3}{|c|}{ Existing } \\
\hline & $(\mathbf{R p})^{*}$ & (USD)* & $(\%)$ & (Rp) & (USD) & $(\%)$ \\
\hline Soil tillage & $1,500,000$ & 107.14 & 11.36 & $1,500,000$ & 107.14 & 14.13 \\
\hline Plotting for planting pads & $7,000,000$ & 500.00 & 53.02 & $4,500,000$ & 321.43 & 42.39 \\
\hline Planting & 715,000 & 51.07 & 5.42 & 715,000 & 51.07 & 6.74 \\
\hline Fertilizing & 550,000 & 39.29 & 4.17 & 550,000 & 39.29 & 5.18 \\
\hline Controlling pests and diseases & $1,512,000$ & 108.00 & 11.45 & $1,701,000$ & 121.50 & 16.02 \\
\hline Turning tendrils & 825,000 & 58.93 & 6.25 & 825,000 & 58.93 & 7.77 \\
\hline Harvesting & $1,100,000$ & 78.57 & 8.33 & 825,000 & 58.93 & 7.77 \\
\hline Total of labor input costs & $13,202,000$ & 943.00 & 100.00 & $10,616,000$ & 758.29 & 100.00 \\
\hline
\end{tabular}

Note. ${ }^{*} 1.0$ USD (US Dollar) $=$ Rp 14,000 (Indonesian Rupiah).

\subsection{Revenue, Benefits, and Financial Feasibility}

The results of research by Masithoh et al. (2017) and Chasanah et al. (2018) showed that the input costs of production facilities took a large portion of the production costs of sweet potato farming, both in innovative and existing technologies, namely $63.07 \%$ and $60.50 \%$, respectively. At the time of the research, the price of sweet potato reached Rp. 3,500 (0.25 USD)/kg at the farmer level, while the yields of both local variety and superior Sari variety using innovation technology reached Rp 3,600 (0.26 USD)/ kg. The price difference was due to the bigger, cleaner and healthier sweet potato Sari variety. By using Sari Variety and innovative technology, farmer income increased by $38.52 \%$ compared to the income of farmers using local variety in the existing way, namely from Rp 42,910,000 (3065.00 USD) to Rp 64,728,000 (4623.43 USD) (Table 3). And if existing farmers (local variety) switched to innovative technology using Sari variety, better land management and control of non-chemical pesticide, the profit increased by $232.47 \%$.

An agricultural commodity is feasible to be developed in terms of increasing productivity and also from the aspect of its agricultural economic feasibility. Sari superior variety using innovative technology is feasible to be developed in South Kalimantan, because it reached a B/C ratio $>1$. The B/C ratio achieved was 1.54 , showed that each additional investment as input for innovative cultivation techniques was able to provide a larger additional income compared to local varieties with existing technology. The application of innovative technology with improved soil cultivation, use of vegetable pesticides and the use of high yielding varieties also provided a high MBCR relative to existing technology. The results of the MBCR analysis reflected the feasibility of changing technology from existing technology to innovation technology. The results showed that if farmers (existing) using local variety switch to innovative technology while still using local variety, then the MBCR achieved is 2.60 and if farmers (existing) with local variety switch to using Sari variety using innovative 
technology then MBCR is 5,51. This means that for every Rp 1,000 (0.14 USD) increase to transform existing technology into innovative technology, there will be an increase in total income of Rp. 5,510 (0.39 USD) (Table 4). This condition causes the innovative technology to have the opportunity to be adopted by farmers, if it can provide a profit of at least $30 \%$ higher than what farmers have been used to. BEP productivity with existing technology (local variety) is $7,617 \mathrm{~kg} / \mathrm{ha}$ at a selling price of Rp 3,500 (0.25 USD)/ kg, while in innovative technology using the Sari variety, BEP of the productivity is $9,733 \mathrm{~kg} / \mathrm{ha}$ at a selling price of $\mathrm{Rp} 3,600(0.26$ USD) $/ \mathrm{kg}$, therefore, total production costs can be covered. Technically, the amount of BEP productivity was achieved at $62.63 \%$ of the real productivity of the existing farmer method, and the BEP productivity of innovation technology was achieved at $40.14 \%$ of the real productivity. From this analysis, it shows that technically and financially that sweet potato farming can provide benefits for farmers.

Table 3. Tuber yield, production costs, revenue and benefit of sweet potato cultivation package technologies in tidal swamp land in Barito Koala, South Kalimantan, Indonesia, 2019

\begin{tabular}{|c|c|c|c|c|c|c|c|}
\hline \multirow{2}{*}{ Cultivation package technologies } & \multirow{2}{*}{$\begin{array}{l}\text { Tuber yield/ha } \\
\text { (tons) }\end{array}$} & \multicolumn{2}{|c|}{ Production costs/ha } & \multicolumn{2}{|c|}{ Revenue/ha } & \multicolumn{2}{|c|}{ Benefit/ha } \\
\hline & & (IDR)* & (USD)* & (IDR)* & (USD)* & (IDR)* & (USD)* \\
\hline \multicolumn{8}{|l|}{ Varieties in Existing } \\
\hline Local & 12.26 & $26,660,000$ & 1904.29 & $42,910,000$ & 3065.00 & $16,250,000$ & 1160.71 \\
\hline Sari & 18.37 & $26,660,000$ & 1904.29 & $64,295,000$ & 4592.50 & $37,635,000$ & 2688.21 \\
\hline \multicolumn{8}{|l|}{ Varieties in Innovative } \\
\hline Local & 17.98 & $35,037,000$ & 2502.64 & $64,728,000$ & 4623.43 & $29,691,000$ & 2120.79 \\
\hline Sari & 24.74 & $35,037,000$ & 2502.64 & $89,064,000$ & 6361.71 & $54,027,000$ & 3859.07 \\
\hline
\end{tabular}

Table 4. The $\mathrm{R} / \mathrm{C}$ ratio, $\mathrm{B} / \mathrm{C}$ ratio, $\mathrm{MBC}$ ratio, and $\mathrm{BEP}$ of sweet potato cultivation package technologies in tidal swamp land in Barito Koala, South Kalimantan, Indonesia, 2019

\begin{tabular}{llllll}
\hline \multirow{2}{*}{ Description } & \multicolumn{2}{c}{ Existing } & & \multicolumn{2}{c}{ Innovative } \\
\cline { 2 - 3 } & Local & Sari & & Local & Sari \\
\hline R/C ratio & 1.61 & 2.41 & & 1.85 & 2.54 \\
B/C ratio & 0.61 & 1.41 & & 0.85 & 1.54 \\
MBC ratio & 0 & 0 & & 2.61 & 5.51 \\
BEP productivity (kg/ha) & 7,617 & 7,617 & & 9,733 & 9,733 \\
BEP price (Rp/kg) & 2,175 & 1,451 & & 1,949 & 1,416 \\
BEP price (USD $/ \mathrm{kg})$ & 0.16 & 0.10 & & 0.14 & 0.10 \\
\hline
\end{tabular}

\section{Discussion}

The difference in the growing environment of sweet potatoes caused the development and yield of sweet potatoes both in quality and quantity to be different (Nedunchezhiyan et al., 2012). Giving straw mulch to sweet potato plantations increased the yield of sweet potatoes, in addition to suppressing weed growth, maintaining moisture and soil fertility (Oliveira et al., 2010; Agbede \& Adekiya, 2011; Wees et al., 2016; Kochmal-Marczak et al., 2018). This was proven by using innovation technology, the tuber yield for Sari variety was higher, both in controlled using chemical insecticides and innovative technology, $18.25 \mathrm{t} / \mathrm{ha}$ and $24.15 \mathrm{t} / \mathrm{ha}$, respectively (Figure 1). The results of the research by Prayogo et al. (2018) indicated that application of B. bassiana without a combination with mulching was able to obtain healthy tuber yield up to 20 tons/ha, the addition of mulch treatment without the combination of B. bassiana produced tuber yields of around 15 tons/ha, whereas without pest control only produced healthy tubers of about 8 tons/ha in tidal fields.

The application of sweet potato cultivation technology packages with improved tillage, land cover with mulch, pest control using chemical fungicides and shallot extracts has proven to be financially feasible. Existing farmers (local variety) who switch to innovative technology using Sari variety, the profit earned increased by $232.47 \%$. Technically, the application of the tuber yield innovative technology for Sari variety was higher, both controlled using chemical insecticides and innovative technology of 18.25 and 24.15 tons/ha, respectively. The implementation of the introduced cultivation technology package was able to increase local sweet potato production to the superior Sari variety by $96.82 \%$ compared to the farmer technology package at the same location. $\mathrm{R} / \mathrm{C}$ and $\mathrm{B} / \mathrm{C}$ ratio $>1$ for innovative technology shows that innovation technology is feasible to be 
developed at the research location. Subagiyo et al. (2005) and Sidik (2007) stated that the relative economic benefits of innovation from an economic perspective must be more profitable, at least moving from 25 to $30 \%$ if the local community wants to adopt it. Social factors and financial aspects in the form of incentives play an important role in determining technology adoption (Sargent et al., 2012; Talukder, 2012; Roumani et al., 2015; Sambodo et al., 2010 in Sirnawati et al., 2019).

This technology package could be introduced in other tidal swamp areas outside the Barito Koala Regency and outside the South Kalimantan Province of Indonesia to support the goverment's food security programs as well as to increase the farmer's welfare.

\section{Acknowledgements}

The authors express their gratitude to the ILETRI Director for providing the financial and logistical support for the successful of this research activity.

\section{References}

Abiodun, D. A. (2010). Bioactivity of powder and extracts from garlic Allium sativum L. (Alliaceae) and spring onion Allium fistulosum L. (Alliaceae) against Callosobruchus maculatus F. (Coleoptera: Bruchidae) on cowpea Vigna unguiculata (L.) Walp (Leguminoceae) seeds. Psyche. Annual Jurnal of Entomology, 20, 1-7. https://doi.org/10.1155/2010/958348

Agbede, T. M., \& Adekiya, A. O. (2011). Evaluation of sweet potato (Ipomoea batatas L.) performance and soil properties under tillage methods and poultry manure levels. Emirates Journal Food Agriculture, 23, 164-177. https://doi.org/10.9755/ejfa.v23i2.6454

Anwar, K., Sabiham, S., Sumawinata, B., Sapei, A., \& Alihamsyah, dan T. (2006). Pengaruh kompos jerami terhadap kualitas tanah, kelarutan $\mathrm{Fe}^{2+}$ dan $\mathrm{SO}_{4}{ }^{2-}$ serta produksi padi pada tanah sulfat masam. J. Tanah dan Iklim, 24, 29-39.

Aribawa, I. B., Supardi, A., Al-Jabri, M., \& Widjaja-Adhi, dan I. P. G. (1997). Rehabilitasi lahan tidur pasang surut jenis sulfat masam di Basarang, Kuala Kapuas, Kalimantan Tengah. In D. U. Kurnia, et al. (Eds.), Prosiding Pertemuan Pembahasan dan Komunikasi Hasil Penelitian Tanah (pp. 155-162).

BALITKABI. (2016). Deskripsi Varietas Unggul. Aneka Kacang dan Umbi. Badan Litbang dan Pengembangan Pertanian.

BBSDLP. (2014). Sumberdaya lahan pertanian Indonesia. Luas, penyebaran dan potensi. Balai Besar Penelitian Pengembangan Pertanian (p. 56). Badan Penelitian dan Pengembangan Pertanian, Bogor.

BPS. (2018). Luas Panen, Produksi dan Produktivitas Ubi jalar dalam Lima Tahun Terakhir. Badan Pusat Statistik. Jakarta, Indonesia.

Caliskan, M. E., Sögüt, T., Boydak, E., Ertük, E., \& Arioglu, H. (2007). Growth, yield, and quality of sweet potato (Ipomoea batatas (L.) Lam.) cultivars in the south-astern Anatolian and east Mediterranean regions of Turkey. Turkey Journal Agriculture, 31, 213-227.

Chalfant, R B., Jansson, R. K., Seal, D. R., Schalk, J. M. (1990). Ecology and management of sweet potato insects. Annual Review of Entomology, 35, 157-180. https://doi.org/10.1146/annurev.en.35.010190.001105

Chalker-Scott, L. (2007). Impact of mulches on landscap plants an the environmental: A review. Journal of Environmental Horticultue, 25, 239-249. https://doi.org/10.24266/0738-2898-25.4.239

Chasanah, L, Sasangko, L. A, \& Subantoro, R. (2018). Analisis Kelayakan Usahatani Ubi Jalar (Ipomoea batatas L.) Varietas Cilembu Di Desa Kepundung Kecamatan Reban Kabupaten Batang. Jurnal Ilmu-Ilmu Pertanian, 14(2), 19-28. https://doi.org/10.31942/md.v14i2.2744

Chen, X. G., Kou, M., Tang, Z. H., Zhang, A. J. \& Li, H. M. (2017). The use of humic acid urea fertilizer for increasing yield and utilization of nitrogen in sweet potato. Plant Soil Environ., 63, 201-206. https://doi.org/ 10.17221/24/2017-PSE

Dada, T. E., Liu, J., Johnson, A. C., \& Gurr, G. M. (2019). Screening barrie plants to reduce crop attack by sweet potato weevil (Cylas formicarius). Pest Management Scince, 76(3), 894-908. https://doi.org/10.1002/ ps.5594

Faidah, U., Subekti, E., \& dan Awami, S. N. (2015). Faktor-faktor yang Mempengaruhi Pendapatan Usahatani Ubi jalar (Ipomoea batatas L.) (Studi Kasus Pada Gapoktan "Nusa Bhakti" Desa Adinuso Kecamatan Reban Kabupaten Batang). MediAgro, 11(2), 60-68. 
Galib, R. (2014). Pengembangan Komoditas Ubi jalar di Lahan Rawa Lebak Kalimantan Srlatan Sebagai Sumber Pangan (Kasus di Kecamatan Daha Utara). Prosiding Seminar Nasional "Inovasi Teknologi Pertanian Spesifik Lokasi”, Banjarbaru.

Handawi, P. S., \& Rachman, D. K. K. (2010). Kajian Keterkaitan Produksi, Perdagangan dan Konsumsi Ubi Jalar untuk Meningkatkan 30\% Partisipasi Konsumsi Mendukung Program Keanekaragaman Pangan dan Gizi.

Hanum, C., Mugnisjah, W. Q., Yahya, S., Sopandy, D., Idris, K., \& Sahar, dan A. (2007). Pertumbuhan akar kedelai pada cekaman aluminium, kekeringan, dan cekaman ganda aluminium dan kekeringan. J. Agritrop., 26(1), 13-18.

Hartatik, W, Aribawa, I. B., \& Adiningsih, dan J. S. (1999). Penelitian pengelolaan hara terpadu pada lahan sulfat masam. In D. F. Agus, et al. (Eds.), Prosiding Seminar Nasional Sumber Daya Tanah, Iklim dan Pupuk (pp. 205-222). Pusat Penelitian Tanah dan Agroklimat, Bogor.

Jakson, D. M., \& Horrison, H. F. (2008). Effect of a killed-cover mulching system on sweet potato production, soil pests, and insect predators in South Carolina. Jouranl of Economic Entomologi, 101, 1871-1880. https://doi.org/10.1603/0022-0493-101.6.1871

Krochmal-Marczak, B, \& Sawicka, B. (2009). The variability of phenotypic features of Ipomoea batatas (L.) Lam. Efficiency growing Ipomoea batatas (L.) Lam. under cover of polyethylene and polypropylene nonwoven the assumed on the flat. Exerc. Probl. Prog. Agric. Sci., 542, 261-270.

Krochmal-Marczak, B., Sawicka, B., \& Tobiasz-Salach, R. (2018). Impact of cultivations technology on the yield of sweet potato (Ipomoea batatas L.) tubers. Emirates Journal of Food and Agriculture, 30(11), 978-983.

Laxminaraya, K., Kuzhivilayil, S. J., Ravindran, C. S., \& Naskar, S. K. (2016). Effect of lime, inorganic and organic source on soil fertility, yield, quality and nutrient uptake of sweet potato in alfisol. Communications in Soil Science and Plant Analysis, 42(20), 2515-2525. https://doi.org/10.1080/00103624.2011.609259

Malian, A. H. (2004). Analisis Ekonomi Usahatani dan Kelayakan Finansial Teknologi pada Skala pengkajian. Pelatihan Analisis Finansial dan Ekonomi bagi Pengembangan Sistem Usahatani Agribisnis Wilayah, Nopember 29-Desember 9, 2004.

Masithoh, S., Novita, I., \& Widara, D. A. (2017). Analisis Pendapatan Usahatani Ubi jalar (Ipomea batatas) Dan Keragaan Penyuluhan Pada Kelompok Tani Hurip di Cikarawang, Dramaga, Bogor. Jurnal AgribiSains, 3(1), 1024. https://doi.org/10.30997/jagi.v3i1.1024

Nedunchezhiyan, M., Byju, G., \& Jata, S. K. (2012). Sweet potato agronomy. Fruit, Vegetable and Sereal Science and Biotechnology, 6(1), 1-10. https://doi.org/10.5402/2012/291285

Noor, M., \& Rahman, A. (2015). Biodiversitas dan kearifan lokal dalam budidaya tanaman pangan mendukung kedaulatan pangan: Kasus di lahan rawa pasang surut. Prosiding Seminar Nasional Masyarakat Biodiversitas Indonesia, 1(8), 1861-1867. https://doi.org/10.13057/psnmbi/m010819

Notohadiprawiro, T., \& Maas, A. (2006). Constraint and prospect of tidal swamp development in Indonesia. Repro: Ilmu Tanah Universitas Gadjah Mada 2006 (p. 11).

Nugroho, K., Alkasuma, P., \& Abdurachman, W. W. dan H. S. (1992). Peta sebaran dan kendala dan arahan pengembangan lahan pasang surut, rawa dan pantai, seluruh Indonesia skala 1:500.000. Bogor: Pusat Penelitian Tanah dan Agroklimat.

Oliveira, A. P., Santos, J. F., Cavalcante, L. F., Pereira, W. E., Santos, M. C. C., Oliveira, A. N. P., \& Silva, N. V. (2010). Yield of sweet potato fertilizer with cattle manure and biofertilizer. Horticultura Brasil, 28, $227-281$. https://doi.org/10.1590/S0102-05362010000300006

Prayogo, Y., Bayu, M. S. Y. I. (2019). Efficacy of biopesticide BeBas against sweet potato weevils (Cylas formicarius Fabricius) in Tidal Land. Jurnal Perlindungan Tanaman Indonesia, 23(1), 6-15. https://doi.org/ 10.22146/jpti.32752

Prayogo, Y., Sumartini, W. Y., Wahyuningsih, S., \& Sutrisno, P. N. (2018). Laporan Hasil Peneleitian. Balai Penelitian Tanaman Aneka Kacang dan Umbi Tahun 2018.

Priatmadi, B. J., Haris, dan A. (2009). Reaksi pemasaman senyawa pirit pada tanah rawa pasang surut. J. Tanah Tropika, 14(1), 19-24. 
Rahim, A. B. D., \& Dan Hastuti, D. R. W. (2007). Ekonomi Pertanian. Penebar Swadaya, Jakarta.

Rehman, M., Liu, J., Johnson, A. C., Dada, T. E., \& Gur, G. M. (2019). Organic muclhes reduce crops attack by sweet potato weevil Cylas formicarius. Science Reports, 16(9), 1-9. https://doi.org/10.1038/s41598-01950521-5

Roumani, Y., Nwankpa, J., \& Roumani, Y. F. (2015). The impact of incentives on the intention to try a new technology. Technology Analysis and Strategic Management, 27(2), 126-141. https://doi.org/10.1080/0953 7325.2014 .952625

Salamiah, K. R. (2016). Mapping of agricultural lands in floid hazard areas in Hulu Sungai Tengah Regency, South Kalimanta. Tropical Westland Journal, 2(3), 22-29. https://doi.org/10.20527/twj.v2i3.36

Saputro, T. B., Prayogo, Y., Rohman, F. L., \& Alami, N. H. (2019). The virulence improvement of Beauveria bassiana in infecting Cylas formicarius modulated by variouse chitin based compound. Biodiversitas, 20(9), 2486-2493. https://doi.org/10.13057/biodiv/d200909

Sargent, K., Hyland, P., \& Sawang, S. (2012). Factor influencing the adoption of information technology in a construction business. Australian Journal of Construction Economics and Building, 12(2), $72-86$. https://doi.org/10.5130/AJCEB.v12i2.2448

Sidik, M. A. (2007). Difusi Inovasi Teknologi Pengelolaan Sampah Pada Masyarakat. J. Tek. Ling., 8(3), 253-260.

Sirnawati, E., \& Sumedi, D. (2019). Faktor Penentu Adopsi Paket Teknologi Jajar Legowo Super: Studi Kasus di Sentra Produksi Padi. Penelitan Pertanian Tanaman Pangan, 3(3), 143-152. https://doi.org/10.21082/jpptp. v3n3.2019.p143-152

Smith, N. E. (1997). The effect of the indigenous cultural practices of in ground storage and piecemeal harvesting of sweet potato on yield and quality losses caused by sweet potato weevil in Uganda. Agriculture Ecosystem Environmental, 64, 191-200. https://doi.org/10.1016/S0167-8809(97)00022-4

Subagyo, R., \& Sekarningsih, R. (2005). Kajian faktor faktor sosial yang berpengaruh terhadap adopsi inovasi usaha perikanan laut di Desa Pantai Selatan Kabupaten Bantul, Daerah Istimewa Yogyakarta. J. Pengkaj Pengemb Teknol Pertan, 8(2), 300-312.

Subiksa, I., Sulaeman, G. M., \& Adhi, dan I. P. G. W. (1998). Perbandingan pengaruh bahan amelioran untuk meningatkan produktivitas lahan gambut. In A. I. Dariah, Jubaedah, Wahyunto, \& D. J. Pitono (Eds.), Prosiding Pertemuan Pembahasan dan Komunikasi Hasil Penelitian Tanah dan Agroklimat. (pp. 119-132). Bogor, India.

Sumartini. (2014). Efficacy of onion (Allium cepa L.) extract as a biofungicide to control scab disease (Sphaceloma batatas) of sweet potato (Ipomoea batatas). Journal of Experiment Biology and Agricultural Science, 2(4), 397-402.

Suryani, R. (2016). Otlook Komoditas Pertanian Tanaman Pangan: Ubi Jalar. Pusat Data dan Sistem 12 Informasi Pertanian Kementrian Pertanian, Jakarta.

Talukder, M. (2012). Factors affecting the adoption of technological innovation by individual employees: An Australian Study. Procedia-Social and Behaviour Science, 40, 52-57. https://doi.org/10.1016/j.sbspro. 2012.03.160

Waluyo, D., \& Mok, I. G. (1994). Ketahanan varietas atau klon ubi jalar terhadap hama lanas (Cylas formicarius F.). In D. A. Winarto, Y. Widodo, S. Antarlina, H. Pudjosantosa, \& D. Sumarno (Eds.), Risalah Seminar Teknologi Produksi dan Pasca Panen Ubi jalar Mendukung Agro-Industri (pp. 216-220). Balittan Malang.

Wees, D., Seguin, P., \& Boisclair, J. (2016). Sweet potato production in a short-season area utilizing black plastic mulch: Effects of cultivar, in-row plant spacing, and harvest on yield parameters. Canada Journal Plant Science, 1, 139-147. https://doi.org/10.1139/cjps-2015-0150

Widodo, Y., Wahyuningsih, S., \& Suhartina, D. (2018). Evaluasi Teknologi Pemupukan pada Ubi Jalar Di Lahan Pasang Surut Kalimantan Selatan (Vol. 2, No. 1). Seminar Nasional Dalam Rangka Dies Natalis UNS Ke 42 Tahun 2018 "Peran Keanekaragaman Hayati untuk Mendukung Indonesia sebagai Lumbung Pangan Dunia”. 
Zahoor, M., Afzal, M., Ali, M., Mohammad, W., Khan, N., Adnan, M., ... Saeed, M. (2016). Effect of organic waste and NPK fertilizer on potato yield and soil fertility. Pure Applied Biology, 5(3), 439-445. https://doi.org/10.19045/bspab.2016.50056

\section{Copyrights}

Copyright for this article is retained by the author(s), with first publication rights granted to the journal.

This is an open-access article distributed under the terms and conditions of the Creative Commons Attribution license (http://creativecommons.org/licenses/by/4.0/). 